\title{
IDENTIFIKASI KUALITAS LAPORAN KEUANGAN MELALUI PEMANFAATAN SISTEM INFORMASI DAN PEMAHAMAN AKUNTANSI BADAN USAHA MILIK DESA DI KABUPATEN MAJALENGKA
}

\author{
Wulan Riyadi ${ }^{1}$ \\ Universitas Majalengka \\ wulanriyadi@unma.ac.id
}

\author{
Melia Wida Rahmayani² \\ Universitas Majalengka \\ meliawidar@unma.ac.id
}

\author{
Yogi Ginanjar ${ }^{3}$ \\ Universitas majalengka \\ yogi.ginanjar@unma.ac.id
}

\begin{abstract}
The factor that can encourage Village Owened Enterprise to become better is the proper management of financial reports. Utilization of information systems and understanding of accounting is important in carrying out Village Owened Enterprise financial activities. Utilization of information systems and understanding of accounting will have an impact on financial reports. Problems related to financial management in Village Owened Enterprise must be considered by the government and other interested parties so that the existence of Village Owened Enterprise continues. This study aims to determine empirical evidence about the effect of the use of information systems and understanding of accounting on the quality of financial reports. The sample in this study was 60 Village Owened Enterprise with sampling using random sampling techniques and obtained of 150 data. The data analysis method used in this study is multiple linear regression. The results of this study indicate that the use utilization of information systems and understanding of accounting has a partial and simultaneous effect on the quality of financial reports. Village Owened Enterprise in Majalengka Regency have implemented an information system to facilitate the preparation and presentation carried out by financial managers who understand accounting science both theory and practice and understand applicable accounting standards so as to produce quality financial reports in Village Owened Enterprise Majalengka Regency.
\end{abstract}

Keywords: the quality of financial reports, utilization of information systems, understanding of accounting

\begin{abstract}
Abstrak
Faktor yang dapat mendorong BUMDes menjadi lebih baik yaitu pengelolaan laporan keuangan yang tepat. Pemanfaatan sistem informasi dan pemahaman akuntansi penting dalam menjalankan aktivitas keuangan BUMDes. Pemanfaatan sistem informasi dan
\end{abstract}


pemahaman akuntansi akan berdampak terhadap laporan keuangan. Masalah yang berkaitan dengan pengelolaan keuangan dalam BUMDes harus diperhatikan oleh pemerintah maupun pihak-pihak berkepentingan agar eksistensi BUMDes terus berlanjut. Penelitian ini bertujuan untuk mengetahui bukti empiris tentang pengaruh pemanfaatan sistem informasi dan pemahaman akuntansi terhadap kualitas laporan keuangan. Sampel dalam penelitian ini sebanyak 60 BUMDes dengan penentuan sampel menggunakan teknik random sampling dan diperoleh 150 data. Metode analisis data yang digunakan dalam penelitian ini yaitu regresi linear berganda. Hasil penelitian ini menunjukkan bahwa pemanfaatan sistem informasi dan pemahaman akuntansi berpengaruh secara parsial dan simultan terhadap kualitas laporan keuangan. BUMDes di Kabupaten Majalengka telah memanfaatkan sistem informasi guna mempermudah dalam penyusunan dan penyajian laporan keuangan. Pengelola keuangan telah memahami ilmu akuntansi baik teori maupun praktik serta paham dengan standar akuntansi yang berlaku sehingga menghasilkan laporan keuangan yang berkualitas di BUMDes Kabupaten Majalengka.

\section{Kata kunci: Kualitas laporan keuangan, Pemanfaatan sistem informasi, Pemahaman akuntansi.}

\section{PENDAHULUAN}

BUMDes dilandasi oleh UU No. 23 Tahun 2014 tentang Pemerintahan Daerah Pasal 213 Ayat (1) disebutkan bahwa "Desa dapat mendirikan badan usaha milik desa sesuai kebutuhan dan potensi desa". Permendagri Nomor 39 Tahun 2010 menyebutkan bahwa "Badan Usaha Milik Desa, yang selanjutnya disebut BUMDes, adalah usaha desa yang dibentuk/didirikan oleh pemerintah desa yang kepemilikan modal dan pengelolaannya dilakukan pemerintah desa dan masyarakat".

Kepala Bidang Pemberdayaan Ekonomi dan Desa menyebutkan bahwa dari 330 desa di Majalengka, sekitar 150 desa yang mulai membangun BUMDes (www.radarcirebon.com, 2019). Faktor yang dapat mendorong BUMDes menjadi lebih baik yaitu pengelolaan laporan keuangan yang tepat.

Laporan keuangan adalah suatu penyajian terstruktur dari posisi keuangan dan kinerja keuangan suatu entitas. Tujuan laporan keuangan adalah memberikan informasi mengenai posisi keuangan, kinerja keuangan, dan arus kas entitas yang bermanfaat bagi sebagian besar kalangan pengguna laporan dalam pembuatan keputusan ekonomi (PSAK No. 1 Tahun 2015). Karena laporan keuangan digunakan sebagai pedoman dalam pengambilan keputusan, maka laporan keuangan harus memiliki karakteristik 
kualitatif yang dapat mendukung tingkat kualitas nilai informasi yang dituangkan di dalamnya. Sehingga pemakai laporan keuangan dapat mengambil keputusan secara efektif.

Kualitas laporan keuangan adalah sejauh mana laporan keuangan yang disajikan menunjukan informasi yang benar dan jujur. Kualitas laporan keuangan berguna sebagai dasar pengambilan keputusan ekonomi bagi pihak yang berkepentingan. Kualitas laporan keuangan dengan berbagai pengukurannya, umumnya digunakan dalam keputusan investasi, perjanjian kompensasi, persyaratan hutang dan keputusan kontrak yang berdasarkan kualitas laporan keuangan (Rosdiani, 2013).

Pemanfaatan sistem informasi akuntansi akan bermanfaat untuk mendukung keputusan yang handal dan memperoleh efektivitas dalam penyampaian informasi. Pengetahuan dan teknologi informasi telah berkembang dengan sangat pesat sehingga sangat mempengaruhi dunia usaha. Teknologi informasi dapat menyediakan sumber informasi secara relevan, tepat, akurat dan lengkap sehingga menjadi suatu kebutuhan dalam dunia usaha (Fedora Calista, 2014).

Poerwadarminta (2006) mengatakan bahwa pemahaman akuntansi adalah proses, cara pembuatan memahami atau memahamkan peranan sumberdaya manusia dalam perkembangan dunia usaha yang saat ini semakin pesat. Kualitas SDM dalam setiap organisasi perusahaan menentukan kesuksesan dalam pencapaian setiap tujuan perusahaan. Seseorang dikatakan paham terhadap akuntansi adalah mengerti dan pandai bagaimana proses akuntansi itu dilakukan sampai menjadi suatu laporan keuangan dengan berpedoman pada prinsip dan standar penyusunan laporan keuangan yang berkualitas.

Penerapan sistem informasi dan pemahaman akuntansi penting dalam menjalankan aktivitas keuangan BUMDes. Sistem informasi dan pemahaman akuntansi akan berdampak terhadap laporan keuangan. Masalah yang berkaitan dengan pengelolaan keuangan dalam BUMDes harus diperhatikan oleh pemerintah maupun pihak-pihak berkepentingan agar eksistensi BUMDes terus berlanjut.

Berdasarkan fenomena yang terjadi maka penulis tertarik melakukan penelitian dengan judul "Identifikasi Kualitas Laporan Keuangan Pemanfaatan Sistem Informasi dan Pemahaman Akuntansi Badan Usaha Milik Desa di Kabupaten Majalengka". 


\section{KERANGKA DAN PENGEMBANGAN HIPOTESIS}

Perkembangan teknologi informasi dalam bidang akuntansi ditandai dengan munculnya aplikasi yang memudahkan bagi seorang akuntan dalam bekerja, maka dalam konteks ini dapat dikatakan bahwa teknologi dengan manusia harus saling berdampingan dan saling keterkaitan dalam menghasilkan laporan keuangan yang berkualitas. Kecakapan seseorang dalam mengoperasikan sistem informasi akan sangat mempengaruhi laporan keuangan yang dihasilkan. Indikator keberhasilan pemanfaatan sistem informasi akuntansi adalah tingkat kualitas laporan keuangan saat menggunakan sistem tersebut.

Untuk mengetahui kualitas laporan keuangan bisa dilihat dari pemanfaatan sistem informasi akuntansi oleh tiap karyawan, ketika sistem informasi memberikan manfaat yang sangat besar atau manfaat dari sistem informasi akuntansi bisa memenuhi kebutuhan akan pengguna maka pengguna sistem informasi akuntansi akan merasa puas pada sistem informasi yang digunakan, sehingga karyawan tersebut akan terus menggunakan sistem informasi akuntansi. Namun ketika sistem informasi tersebut dirasakan kurang bermanfaat maka kualitas laporan keuangan yang rasakan akan berkurang, dan kemungkinan akan meninggalkan sistem informasi akuntansi.

Hasil penelitian Meilani Purwanti, Wasma (2014) mengemukakan bahwa pemanfaatan sistem informasi akuntansi mempunyai pengaruh positif signifikan terhadap kualitas laporan keuangan, dimana semakin tinggi manfaat yang dirasakan maka seseorang akan terus menggunakan sistem tersebut. Dengan adanya fasilitas jaringan sistem informasi akuntansi yang dirancang khusus untuk proses penyusunan laporan keuangan mulai dari pencatatan jurnal, buku besar sampai kepada laporan keuangan semua telah tersistem dengan menggunakan komputerisasi akan mengurangi tingkat kesalahan dalam perhitungan dan menghemat waktu dalam proses penyusunannya. Sehingga laporan yang dihasilkan dapat memenuhi informasi yang diharapkan dan mampu meningkatkan kualitas hasil serta tersedianya laporan keuangan yang tepat waktu.

\section{$H_{1}$ : Pemanfaatan sistem informasi berpengaruh terhadap kualitas laporan keuangan.}


Sumber daya manusia adalah bagian dari sistem dalam penyusunan laporan keuangan. Manusia sebagai user berperan vital di dalam penyusunan laporan keuangan, pemahaman yang dikuasai dan kecakapan dalam mengoperasikan perangkat informasi berpengaruh signifikan dalam penyajian laporan keuangan.Widodo (2011) menjelaskan kompetensi sumber daya manusia adalah kemampuan sumber daya manusia untuk melaksanakan tugas dan tanggung jawab yang diberikan kepadanya dengan bekal pendidikan, pelatihan, dan pengalaman yang cukup memadai. Sumber Daya Manusia (SDM) yang kompeten tersebut akan mampu memahami logika akuntansi dengan baik.

Hasil penelitian Dian Irma Diani (2014) mengemukakan bahwa Pemahaman Akuntansi mempunyai pengaruh terhadap kualitas laporan keuangan, dimana semakin banyak pemahaman akuntansi yang dikuasai maka kualitas laporan keuangan semakin baik.

\section{$H_{2}$ : Pemahaman akuntansi berpengaruh terhadap kualitas laporan keuangan.}

Sumber Daya Manusia (SDM) adalah faktor terpenting dalam penyusunan laporan keuangan yang berkualitas dimana tingkat pemahaman dan intelektual seorang akuntan berpengaruh terhadap kualitas laporan keuangan yang dihasilkan. Indikator dari laporan keuangan sehingga dikatakan berkualitas adalah laporan keuangan tersebut diantaranya relevan, dapat dipahami, tepat waktu. Selain kualitasnya dari SDM-nya, laporan keuangan akan dapat tersaji secara berkualitas juga didukung dengan suatu sistem yang baik. Sistem informasi akuntansi adalah perangkat yang membantu akuntan menyelesaikan pekerjaanya, pemanfaatan SIA sangat berpengaruh terhadap kinerja perusahaan, seperti yang diungkapkan. Dari dua hal tersebut dapat kita garis bawahi bahwa keduanya memiliki peran penting dalam hal terciptanya laporan keuangan yang berkualitas, lain dari itu keduanya juga pada era globalisasi memiliki peran yang saling berkaitan bahkan tidak terpisahkan Dian Irma Diani (2014).

\section{$\mathrm{H}_{3}$ : Pemanfaatan sistem informasi dan pemahaman akuntansi berpengaruh terhadap kualitas laporan keuangan.}

\section{METODE PENELITIAN}

Metode penelitian yang digunakan adalah metode survey dengan pendekatan analisis deskriftif dan verifikatif. Data yang digunakan adalah data primer yang diperoleh dari responden. 


\section{Variabel Independen $(\mathbf{X})$}

a. Pemanfaatan system informasi $\left(\mathrm{X}_{1}\right)$

Variabel ini memiliki 8 item pernyataan dengan pengukuran skor jawaban responden menggunakan skala ordinal (skala likert) 5 alternatif yang terdiri atas : Sangat Setuju $(\mathrm{SS})=5$, Setuju $(\mathrm{S})=4$, Kurang Setuju $(\mathrm{KS})=3$, Tidak Setuju $($ TS $)=2$, Sangat Tidak Setuju $($ STS $)=1$.

b. Pemahaman Akuntansi $\left(\mathrm{X}_{2}\right)$

Variabel ini memiliki 10 item pernyataan dengan pengukuran skor jawaban responden menggunakan skala ordinal (skala likert) 5 alternatif yang terdiri atas : Sangat Setuju $(\mathrm{SS})=5$, Setuju $(\mathrm{S})=4$, Kurang Setuju $(\mathrm{KS})=3$, Tidak Setuju $(\mathrm{TS})=2$, Sangat Tidak Setuju $($ STS $)=1$.

\section{Variabel Dependen (Y)}

Variabel ini memiliki 9 item pernyataan dengan pengukuran skor jawaban responden menggunakan skala ordinal (skala likert) 5 alternatif yang terdiri atas : Sangat Setuju $(S S)=5$, Setuju $(S)=4$, Kurang Setuju $(K S)=3$, Tidak Setuju $(T S)=2$, Sangat Tidak Setuju $($ STS $)=1$.

\section{Populasi dan Sampel}

Populasi dalam penelitian ini adalah pengurus BUMDes di Kabupaten Majalengka terdiri dari direktur BUMDes, Bendahara, Bagian Accounting. Teknik sampling menggunakan random sampling sehingga diperoleh sampel sebanyak 150 dari berbagai Desa yang ada di Kabupaten Majalengka.

\section{Analisis Data}

Analisis data pada penelitan ini yaitu uji instrumen penelitian yaitu uji validitas dan reliabilitas, transformasi data, uji asumsi klasik (uji normalitas, uji multikolinearitas, uji heteroskedastisitas), analisis regresi linier berganda, koefisien determinasi dan uji hipotesis dengan menggunakan aplikasi SPSS. 


\section{Analisis Regresi Linier Berganda}

\section{Tabel 1}

\section{Hasil Regresi Linear Berganda}

\begin{tabular}{|c|c|c|c|c|c|c|}
\hline \multicolumn{7}{|c|}{ Coefficients } \\
\hline \multirow{2}{*}{\multicolumn{2}{|c|}{ Model }} & \multicolumn{2}{|c|}{$\begin{array}{c}\text { Unstandardized } \\
\text { Coefficients }\end{array}$} & \multirow{2}{*}{$\begin{array}{c}\begin{array}{c}\text { Standardized } \\
\text { Coefficients }\end{array} \\
\text { Beta }\end{array}$} & \multirow[t]{2}{*}{$\mathrm{T}$} & \multirow[t]{2}{*}{ Sig. } \\
\hline & & B & Std. Error & & & \\
\hline \multirow{4}{*}{1} & (Constant) & 19,694 & 5,588 & & 3,038 & 3,006 \\
\hline & Pemanfaatan Sistem & , 191 &, 117 & ,266 & 1,997 & 023 \\
\hline & Informasi & & & & & \\
\hline & Pemahaman Akuntansi & 3,733 & , 133 &, 425 & 3,187 & 1,975 \\
\hline
\end{tabular}

a. Dependent Variable: Kualitas Laporan Keuangan

Sumber: Output SPSS 21 (Diolah Sendiri, 2021)

\section{Analisis Koefisien Determinasi}

Untuk mengetahui seberapa besar pengaruh koefisien determinasi digunakan rumus sebagai berikut (Sugiyono, 2014:231).

$$
\mathrm{Kd}=\mathrm{r}^{2} \times 100 \%
$$

Keterangan :

$\mathrm{Kd}=$ Koefisien Determinasi

$\mathrm{r}^{2}=$ Nilai koefisien determinasi

\section{Uji Hipotesis}

\section{Uji Parsial}

Pengujian ini dilakukan dengan cara membandingkan $t$ hitung dengan $t$ tabel pada tingkat signifikan $\alpha 5 \%$ dengan $\mathrm{dk}=\mathrm{n}-1$.

$$
t_{\text {hitung }}=\frac{r \sqrt{n-2}}{\sqrt{1-r^{2}}}
$$

Keterangan:

$$
\begin{array}{ll}
\mathrm{t}_{\text {hitung }} & =\text { Nilai } \mathrm{t} \\
\mathrm{r} & =\text { Nilai koefisien korelasi } \\
\mathrm{n} & =\text { Jumlah sampel }
\end{array}
$$


Berdasarkan rumusan masalah dan hipotesis maka dilakukan uji hipotesis dengan ketentuan sebagai berikut:

H1: Ada pengaruh antara batasan waktu audit terhadap kualitas audit.

H2: Ada pengaruh antara pengalaman terhadap kualitas audit.

\section{Uji Simultan}

Untuk pengujian secara simultan maka digunakan uji F. Uji $\mathrm{F}$ adalah alat menguji variabel independen secara bersama terhadap variabel dependennya untuk meneliti apakah model dari penelitian tersebut sudah fit (sesuai) ataukah tidak sesuai. Dapat dihitung dengan rumus menurut Sugiyono (2014:192) sebagai berikut :

$$
\mathrm{F}_{\text {hitung }}=\frac{R^{2} / k}{\left(1-R^{2}\right) /(n-k-1)}
$$

Keterangan:

$\mathrm{n}=$ Jumlah responden

$\mathrm{k}=$ Jumlah variabel bebas (independen)

$\mathrm{R}^{2}=$ Koefisien korelasi ganda

\section{HASIL PENELITIAN DAN DISKUSI}

\section{Pengaruh Pemanfaatan Sistem Informasi Akuntansi Terhadap Kualitas Laporan Keuangan}

Hasil Analisis Regresi Linear Berganda pada tabel 1 menunjukan $t$ hitung variabel pemanfaatan system informasi akuntansi adalah sebesar 0,191 bernilai positif dengan tingkat signifikansi sebesar 0,023. Karena nilai $\mathrm{t}_{\text {hitung }}<\mathrm{t}_{\text {tabel }}$ yaitu 0,832 <1,975 dan nilai signifikansinya $0,023<0,05$ maka Ha ditolak dan Ho diterima. Dengan demikian Hipotesis pertama terbukti kebenarannya. Hal ini sesuai dengan teori yang menyatakan bahwa untuk terselenggaranya proses penyampaian informasi yang cepat dan akurat sehingga dapat menghasilkan laporan keuangan yang baik, pemerintah pusat dan daerah berkewajiban untuk mengembangkan dan memanfaatkan kemajuan teknologi informasi. Dalam kerangka ini, undang-undang nomor 33 tahun 2004 tentang perimbangan 
keuangan pemerintah pusat dan daerah mengamanatkan adanya dukungan sistem informasi keuangan daerah yang diselenggarakan secara nasional Ahmad (2008). Pemanfaatan sistem informasi akuntansi merupakan suatu manfaat bagi para pemakai sistem informasi untuk menjalankan kewajibannya, pengukurannya berlandaskan kepada intensitas kegunaan, frekuensi penggunaan dan jumlah sofware yang digunakan (Alni Rahmawati, 2014). Hasil penelitian ini konsisten mendukung hasil penelitian Mahaputra dan Wayan (2014) yang menyimpulkan pemanfaatan sistem informasi keuangan daerah berpengaruh positif dan signifikan terhadap kualitas informasi pelaporan keuangan pemerintah daerah.

Hal ini disebabkan karena laporan keuangan BUMDes di Kabupaten Majalengka dipengaruhi pemanfaatan sistem informasi akuntansi dimana teknologi informasi di setiap BUMDes sudah diterapkan dan dimanfaatkan dengan baik guna mempermudah dalam pencatatan akuntansi untuk menyusun laporan keuangan dengan cepat dan tepat. Penyajian laporan keuangan dihasilkan oleh orang-orang yang paham betul dalam ilmu akuntansi baik teori maupun praktek serta paham dengan standar akuntansi yang berlaku sehingga menghasilkan laporan keuangan yang berkualitas di setiap BUMDes Kabupaten Majalengka.

\section{Pengaruh Pemahaman Akuntansi Terhadap Kualitas Laporan Keuangan}

Hasil Analisis Regresi Linear Berganda menunjukan t hitung variabel pemahaman akuntansi adalah sebesar 3.733 bernilai positif dengan tingkat signifikansi sebesar 0,000 . Karena nilai $t_{\text {hitung }}<\mathrm{t}$ tabel yaitu $3.733>1,975$ dan nilai signifikansinya $0,000>$ 0,05 maka Ha ditolak dan Ho diterima. Dengan demikian Hipotesis kedua terbukti kebenarannya.

Hasil penelitian ini sejalan dengan dengan teori yang dikemukakan oleh (Poerwadarminta:2006) pemahaman akuntansi merupakan suatu kemampuan seseorang untuk mengenal dan mengerti benar tentang akuntansi. Untuk dapat menghasilkan laporan keuangan yang berkualitas maka kualitas orang-orang yang melaksanakan tugas dalam menyusun laporan keuangan harus menjadi perhatian utama yaitu para karyawan yang terlibat dalam aktivitas tersebut harus mengerti dan memahami bagaimana proses dan pelaksanaan akuntansi itu dijalankan dengan berpedoman pada ketentuan yang berlaku. 
Penelitian ini juga sejalan dengan penelitian yang dilakukan oleh Yuliani (2010) yang menunjukkan adanya pengaruh pemahaman akuntansi terhadap kualitas laporan keuangan pemerintah. Hal ini mengungkapkan bahwa untuk dapat menghasilkan laporan keuangan yang berkualitas maka kualitas orangorang yang melaksanakan tugas dalam menyusun laporan keuangan harus menjadi perhatian utama yaitu para pegawai yang terlibat dalam aktivitas tersebut harus mengerti dan memahami bagaimana proses dan pelaksanaan akuntansi itu dijalankan dengan berpedoman pada ketentuan yang berlaku.

Hal ini disebabkan karena tingkat pemahaman akuntansi mengenai ilmu akuntansi yang dimiliki oleh setiap pengelola BUMDes bagian keuangan memiliki pemahaman yang cukup baik dalam menyusun laporan keuangan hal ini berdasarkan pada kemampuan pengelola BUMDes dalam melaksanakan serta menyelesaikan laporan bulanan BUMDes tepat waktu.

\section{Pengaruh Pemanfaatan Sistem Informasi Akuntansi, Pemahaman Akuntansi Terhadap Kualitas Laporan Keuangan}

Berdasarkan tabel di atas nilai Sig. 0,000 lebih kecil dari probabilitas 0,05 atau $0,000<0,05$ dan nilai $F_{\text {hitung }}>\mathrm{F}$ tabel yaitu $19.694>3.06$ maka Ho ditolak dan Ha diterima. Hal ini berarti pemanfaatan system informasi akuntansi dan pemahaman berpengaruh terhadap kualitas laporan keuangan. Hal ini sesuai dengan teori yang dinyatakan oleh Ahmad (2008) bahwa untuk terselenggaranya proses penyampaian informasi yang cepat dan akurat pemanfaatan teknologi informasi dapat menghasilkan laporan keuangan yang baik.

Teori yang dikemukakan oleh Poerwadarminta (2006) pemahaman akuntansi merupakan suatu kemampuan seseorang untuk mengenal dan mengerti benar tentang akuntansi. Untuk dapat menghasilkan laporan keuangan yang berkualitas maka kualitas orang-orang yang melaksanakan tugas dalam menyusun laporan keuangan harus menjadi perhatian utama yaitu para karyawan maupun pengelola yang terlibat dalam aktivitas tersebut harus mengerti dan memahami bagaimana proses dan pelaksanaan akuntansi itu dijalankan dengan berpedoman pada ketentuan yang berlaku.

Hal ini disebabkan karena BUMDes di Kabupaten Majalengka mengenai laporan keuangan dipengaruhi pemanfaatan sistem informasi akuntansi dimana teknologi informasi di setiap BUMDes sudah diterapkan dan dimanfaatkan dengan baik 
untuk mempermudah dalam pencatatan akuntansi untuk menyusun laporan keuangan dengan cepat dan tepat. Penyajian laporan keuangan dihasilkan oleh orang-orang yang paham betul dalam ilmu akuntansi baik teori maupun praktek serta paham dengan standar akuntansi yang berlaku sehingga menghasilkan laporan keuangan yang berkualitas di BUMDes Kabupaten Majalengka.

\section{KESIMPULAN, IMPLIKASI DAN KETERBATASAN PENELITIAN}

Pemanfaatan sistem informasi berpengaruh positif dan signifikan terhadap kualitas laporan keuangan. Sistem informasi di setiap BUMDes sudah diterapkan dan dimanfaatkan dengan baik guna mempermudah dalam pencatatan akuntansi untuk menyusun laporan keuangan dengan cepat dan tepat. Pemahaman akuntansi berpengaruh positif dan signifikan terhadap kualitas laporan keuangan. Hal ini disebabkan karena tingkat pemahaman akuntansi bagian keuangan pengelola BUMDes cukup baik dalam menyusun laporan keuangan. Hal ini dibuktikan pada kemampuan pengelola BUMDes dalam melaksanakan serta menyelesaikan laporan bulanan BUMDes tepat waktu. Pemanfaatan sistem informasi dan pemahaman akuntansi berpengaruh positif dan signifikan terhadap kualitas laporan keuangan. Penyajian laporan keuangan dihasilkan oleh orang-orang yang paham betul dalam ilmu akuntansi baik secara teori maupun praktek serta paham dengan standar akuntansi yang berlaku sehingga menghasilkan laporan keuangan yang berkualitas di BUMDes Kabupaten Majalengka.

Hasil penelitian ini berimplikasi untuk penguatan pengelolaan BUMDes terkait kualitas laporan keuangan khususnya dilihat dari sudut pandang pemanfaatan sistem informasi dan pemahaman akuntansi. Sedangkan keterbatasan penelitian ini adalah bahwa hasil penelitian ini tidak dapat digeneralisasi ke semua bentuk organisasi, hanya berlaku untuk BUMDes. Diharapkan selanjutnya dapat memperluas target populasi dan menggunakan metode penelitian yang berbeda.

\section{DAFTAR PUSTAKA}

Ahmad, Saebani Beni. 2008. Metode Penelitian. Bandung : Pustaka Setia

Alni, Rahmawati, dkk., 2014, Statistika Teori dan Praktek, Edisi II. Universitas Muhammadiyah Yogyakarta, Yogyakarta. 
Arlia Sari Artana. 2016. "Pengaruh Pemahaman Standar Akuntansi Pemerintah, Pemanfaatan Sistem Informasi Akuntansi Keuangan Daerah, dan Pengandalian Internal Terhadap Kualitas Laporan Keuangan Pemerintah Daerah".Jurnal. Universitas Negeri Syarif Hidayatullah, Jakarta.

Calista, Fedora. 2014. "Pengaruh Implementasi Enterprise Resource Planning (ERP) Terhadap Kualitas Informasi Pada PT Otsuka Indonesia.

Dian Irma Diani (2014).PengaruhPemahaman Akuntansi, Pemanfaatan Sistem Informasi Akuntansi Keuangan Daerah dan Peran Internal Audit terhadap Kualitas Laporan Keuangan Pemerintah Daerah (Studi Empiris Pada Satuan kerja Perangkat Daerah KotaPariaman).Jurnal Akuntansi Vol.2 No.1.

Ikatan Akuntan Indonesia. 2015. PSAK No. 1 Tahun 2015 tentang penyajian Laporan Keuangan.

Mahaputra, Putu Upabayu Rama dan Wayan Putra.2014.Analisis Faktor-Faktor Yang Mempengaruhi Kualitas Informasi Pelaporan Keuangan Pemerintahan Daerah.Jurnal Akuntansi Universitas Udayana , ISSN :2302-8556

Meilani Purwanti, Wasman (2014). Pengaruh PemahamanAkuntansi, pemanfaatan sistem informasia kuntansi,danperan internal audit terhadap kualitas laporan keuangan .(survai pada koperasi pegawai republik Indonesia kota Bandung. Jurnal bisnisdanmanajemen vol.4 no. 2

Permendagri N0 39 tahun 2010 tentang Badan Usaha Milik Desa.

Permendagri No. 1 Tahun 2015 tentang Pedoman Kewenangan Berdasarkan Hak Asal Usul dan Kewenangan Lokal Berskala Desa.

Poerdarminta. 2006. Kamus Umum Bahasa Indonesia. Balai Pustaka. Jakarta.

Rosdiani, Hayyuning Tyas. 2013. "Pengaruh Sistem Pengendalian Internal Audit Laporan Keuangan dan Penerapan Good Corporate Governance terhadap Kualitas Laporan Keuangan. Jurnal. Universitas Islam Syarif Hidayatullah.

SAK ETAP Tahun 2012 tentang laporan keuangan.

Sugiyono. 2013. Metode Penelitian Pendidikan Pendekatan Kuantitatif, Kualitatif dan R\&D. Bandung: Alfabeta.

Undang Undang No 33 Tahun 2004 tentang Perimbangan Keuangan antara Pemerintah dan Pemerintahan Daerah.

Undang-Undang No 23 Tahun 2014 tentang Pemerintah Daerah.

Widodo. 2011. Analisis kebijakan publik: Konsep dan Aplikasi Analisis Proses Kebijakan Publik. Malang: Bayu Media.

Wilfa, Razannisa. 2016. "Pengaruh persepsi pemilik terhadap laporan keuangan dan pemahaman Akuntansi Pelaku Usaha Terhadap Kualitas Laporan Keuangan UMKM Fashion di Kabupaten Sleman”. Jurnal.Universitas Negeri Yogyakarta. www.radarcirebon.com di akses pada hari senin 5 Agustus 2019.

Yuliani. 2010. "Pengaruh pemahaman Akuntamsi Pemanfaatan Sistem Informasi Akuntansi Keuangan Daerah dan Peran Internal Audit Terhadap Kualitas Laporan Keuangan Pemerintah Daerah (Studi pada Pemerinatah Kota Banda Aceh).Jurnal Riset Akuntansi Vol 3.No.2 hal 206 -220. 